\title{
Seed physiological quality and harvest point of dovyalis fruits ${ }^{1}$
}

\author{
Fabíola Villa², Daniel Fernandes da Silva², \\ Maria Cristina Copello Rotili², Neusa Francisca Michelon Herzog², Marlene de Matos Malavasi
}

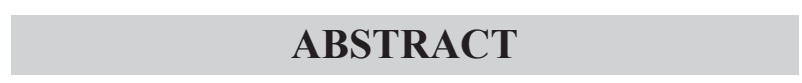

The main propagation mode of dovyalis is by seeds, what makes important to determine the ideal moment of fruit harvest. This study aimed to evaluate the physiological seed quality and harvest time of dovyalis fruits. To determine the fruit physical attributes, they were visually classified into five classes, according to the maturity stages, based on the external color of the exocarp: stage 1: green fruit; stage 2: yellowish-green; stage 3: yellowish-brown; stage 4: brown; stage 5: intense brown. The seed extraction to evaluate the physiological quality was based on the seed water content, germination percentage, germination speed index and determination of the dry biomass of the shoot, root and seedlings originated from these seeds. The experimental design was completely randomized, containing 25 seeds per treatment and 4 replicates. The fruit color during ripening varies from green to intense brown. The fruits reach their largest size and fresh biomass accumulation in the stage 4, with the brown exocarp color represented in the Munsell chart by $2.5 \mathrm{YR} 3 / 4$. The removal of seeds for propagation should occur from the stage $2(2.5 \mathrm{GY} 5 / 8)$, when the fruits have a yellowish-green color, although no statistical variation is observed in the number of seeds during maturation.

KEYWORDS: Dovyalis hebecarpa (Gardner) Warb., sexual propagation, fruit maturation.

\section{INTRODUCTION}

Dovyalis hebecarpa (Gardner) Warb. is a shrub species that belongs to the Salicaceae family. The fruits are spherical berries known as Ceylon gooseberry, ketembilla or kitembilla. The flesh is characterized by a purple-reddish exocarp, with several seeds distributed in the mesocarp. The fruits can be consumed in natura after the exocarp

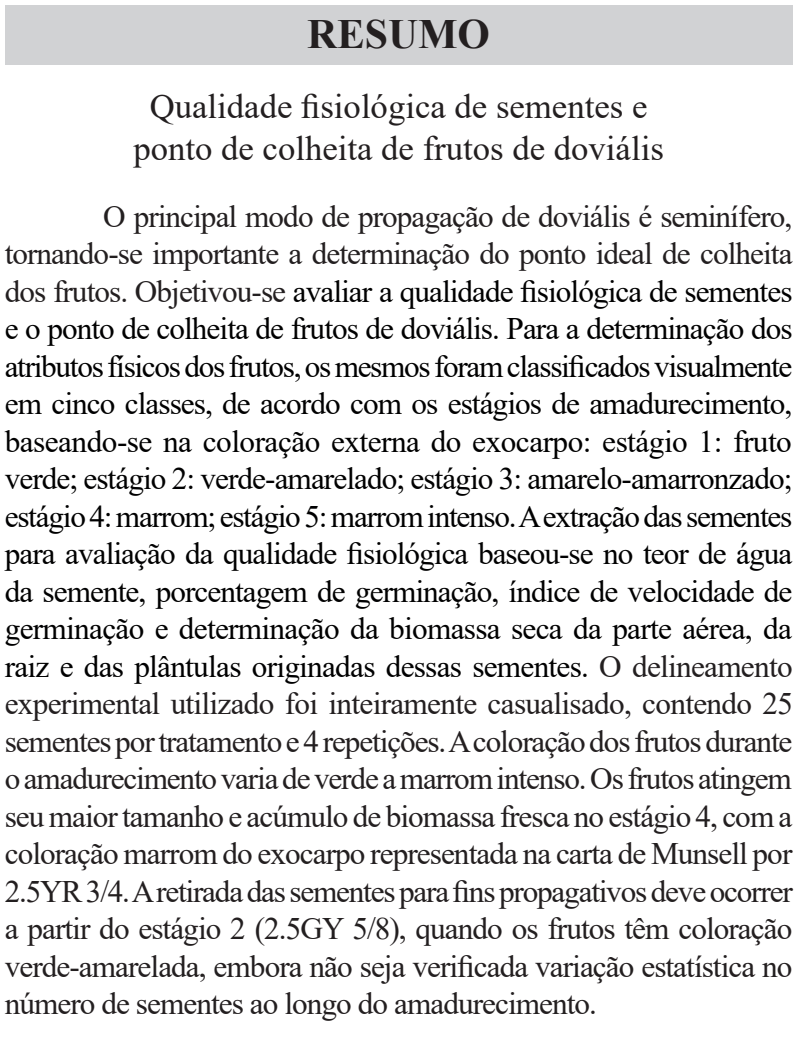

PALAVRAS-CHAVE: Dovyalis hebecarpa (Gardner) Warb., propagação sexuada, maturação de fruto.

removal, as it does not present a pleasant texture to the palate, and also used in jellies and juices after being processed (Bochi et al. 2014, Rotili et al. 2018).

Dovyalis is originally from south India and Ceylon Island (Sri Lanka) and, due to its nutritional importance and easy adaptation, it is currently found in all continents (Almeida et al. 2007), being recently cultivated in the southeast region of Brazil, with

1. Received: Aug. 20, 2018. Accepted: Mar. 20, 2019. Published: Jun. 17, 2019. DOI: 10.1590/1983-40632019v4954520.

2. Universidade Estadual do Oeste do Paraná, Centro de Ciências Agrárias, Marechal Cândido Rondon, PR, Brasil.

E-mail/ORCID: fvilla2003@hotmail.com/0000-0002-3739-5160,daniel_eafi@yahoo.com.br/0000-0003-2105-5839, mcrotili@hotmail.com/0000-0002-5029-2748,neuzaherzog@hotmail.com/0000-0001-5644-7387, 
concentrated production peaks between March and May (Bochi et al. 2014).

The species can be propagated by several methods (Rinaldi et al. 2017), but the main way of obtaining seedlings is from seeds (Almeida et al. 2004), and the first step to success in its sexual propagation is selecting high-quality seeds. The maximum physiological seed quality for germination and vigor is traditionally associated with dry biomass accumulation (Marcos Filho 2015), which, in fleshy fruits, usually occurs concomitantly with the first changes in the exocarp color, such as in melon (Donato et al. 2015).

Marcos Filho (2015) affirms that the seeds of most species have the ability to germinate before reaching their physiological maturity. According to Carvalho \& Nakagawa (2012), the fruit exocarp color can be a seed-quality identifier, what highlights the importance of observing this attribute to determine the appropriate time of fruit harvest, when looking for seeds with complete morphological development and physiological maturation. Precocious harvest may interrupt the fruit maturation process and negatively influence the seed quality (Rubio et al. 2013).

Dovyalis fruits go through several physical modifications from the beginning of development until reaching the full maturation stage, including changes in the exocarp size and color (from completely green to intense brown). This study aimed to evaluate dovyalis fruits at various stages of maturation, as well as to correlate them with seed development, allowing the determination of the ideal fruit harvest stage in which the physiological quality of the seeds reaches the highest potential for use in sexual propagation.

\section{MATERIAL AND METHODS}

The fruits were harvested in March 2016, from four-year-old plants located at an orchard of the Universidade Estadual do Oeste do Paraná, in Marechal Cândido Rondon, Paraná state, Brazil.

For determining the physical fruit attributes (color, fresh biomass, transversal and longitudinal diameters) (Sbrussi et al. 2014, Kaiser et al. 2016), four replicates of 25 fruits per class (100 fruits per class in total) were analyzed and visually classified in five classes, according to the ripening stage indicated by the exocarp color [stage 1: green fruit; stage 2: yellowish-green (less than $50 \%$ of brownish exocarp); stage 3: brownish-yellow (50\% of brownish exocarp); stage 4: brown (more than $50 \%$ of brownish exocarp); stage 5: intense brown (completely brown)]. The visual classification of the exocarp was based on the Munsell (1976) chart, with pigmentation quantified by the color spectrum reflectance ratio of red, green and blue, and a color analyzer (brand Instrutemp ${ }^{\circledR}$, model ITACR-135). Values were expressed in a scale between 0 and 255 for each attribute, according to the RGB additive color system.

The fruit fresh biomass $(\mathrm{g})$ was determined on an analytical digital scale. The longitudinal and transversal diameters $(\mathrm{cm})$ were measured with analog calipers from the greatest distance between the peduncle insertion point and the opposite distal part of the fruit and opposite points of the greatest fruit width.

After evaluating the physical attributes of the fruits, the seeds were extracted for physiological quality evaluations. The seeds were extracted with a scalpel, separating them from the mesocarp. The number of seeds per fruit at each maturation stage was determined by manual counting. In this evaluation, 4 replicates of 25 fruits were used at each ripening stage, with the number of seeds per fruit calculated as the mean number of seeds in the fruits of these four replications.

As the fruits presented a small number of seeds, more fruits in the same maturation stage were used to extract seeds to reach the required quantity for the seed physiological quality determination. After extraction and counting, seeds were washed in running water and immersed in a distilled water + sodium hypochlorite $2.5 \%$ solution for $5 \mathrm{~min}$ and then rinsed in distilled water (Jesus et al. 2016).

After the seed extractions, the water content was determined by drying the seeds in an oven with forced air circulation at $105 \pm 3{ }^{\circ} \mathrm{C}$, for $24 \mathrm{~h}$ (Brasil 2009), using 4 samples of 25 seeds for each fruit maturation stage, being each sample one replicate.

The germination test was conducted in a germination chamber (BOD) with a 12-h photoperiod and temperature of $30{ }^{\circ} \mathrm{C}$ during the light period and $25^{\circ} \mathrm{C}$ during the dark period (Zucareli et al. 2015). Four replicates of 25 seeds were used for each maturation stage and arranged manually in plastic germination boxes $(11 \mathrm{~cm} \times 11 \mathrm{~cm} \times 3 \mathrm{~cm})$ that contained two sheets of paper towel moistened with an amount of water equivalent to 2.5 times the paper 
weight (Brasil 2009). The germination speed index (GSI) was calculated at 30 days after the installation of the experiment, when germination stabilized, using the formula proposed by Maguire (1962): $\mathrm{GSI}=\left(\mathrm{G}_{1} /\right.$ $\left.\mathrm{N}_{1}\right)+\left(\mathrm{G}_{2} / \mathrm{N}_{2}\right)+\ldots+\left(\mathrm{G}_{\mathrm{n}} / \mathrm{N}_{\mathrm{n}}\right)$, where, $G_{1}, G_{2}$ and $G_{n}$ are the number of plantlets in the first, second and final germination counts, respectively, and $N_{1}, N_{2}$ and $N_{n}$ the number of days of sowing at the first, second and last counts, respectively.

The seedling quality was determined using five seedlings randomly collected per replicate, which were separated into root and shoot and dried in an oven with forced air circulation at $65 \pm 2{ }^{\circ} \mathrm{C}$ until they reached a constant biomass weight. The dried seedlings were then weighted for the dry biomass determination of shoots, seedlings and roots (Lessa et al. 2014).

The qualitative averages of the variables were submitted to analysis of variance and compared by the Tukey test with $5 \%$ of error probability, and the quantitative variables were submitted to regression using the Sisvar statistical software (Ferreira 2011).

\section{RESULTS AND DISCUSSION}

According to the Munsell chart (Munsell 1976), the dovyalis fruits underwent exocarp color modifications during development and maturation (Table 1).

The stages started with green colored fruits (2.5GY 6/6), before the fruits reached the maximum size to initiate a color change. The dovyalis fruits acquired a yellowish-green color $(2.5 \mathrm{GY} 5 / 8)$ in the next development stage and a brownish-yellow color $(2.5 Y R 4 / 6)$ after that. The fruits were completely brown in the next development stage, but at a low intensity (2.5YR 3/4), and, finally, the exocarp acquired an intense brown appearance (2.5YR 3/6).

The Munsell chart is an important tool that allows to characterize the progression of fruit maturation stages, because a color scale can be attributed throughout the process of fruit growth and development, making it possible to associate the fruit exocarp color to a specific phase of interest. Some studies have been conducted using the Munsell chart to show the phase where the seeds are completely physiologically mature, as it happened for Jatropha curcas L. (Rubio et al. 2013) and Allophylus edulis [(A. St.-Hil., A. Juss. \& Cambess.) Hieron. ex Niederl.] (Kaiser et al. 2016).
Based on the graphic representation of the colors by values obtained with red, green and blue spectrum readings that were represented in the RGB color system software (Table 2), a green spectrum superiority is observed only in the first analyzed stage, confirming a lower degree of fruit maturation at this stage. In the second stage, the red spectrum prevails in all the others, demonstrating the maturation progress.

The results corroborate studies conducted by Cavalini et al. (2015) with Paluna and Kumagai guava fruits (Psidium guajava L.). The same authors observed an exocarp color change throughout the different maturation phases and loss of the initial green color. They also affirm that the loss of the green color is a characteristic of ripening and occurs due to chlorophyll degradation and the appearance of other peculiar pigments of ripened fruit, such as anthocyanins.

Another important aspect is the reflectance reduction of the three light spectra with the fruit ripening advancement. There was no significant difference in the reflectance between the first and second stages, but reduced values of red, green and blue were verified in the third stage. The reflectance

Table 1. Fruit classification by visual aspect (Munsell 1976).

\begin{tabular}{|c|c|c|}
\hline $\begin{array}{l}\text { Fruit } \\
\text { stage }\end{array}$ & $\begin{array}{l}\text { Color } \\
\text { code }\end{array}$ & $\begin{array}{c}\text { External fruit } \\
\text { appearance (exocarp) }\end{array}$ \\
\hline Green (1) & $2.5 \mathrm{GY} 6 / 6$ & \\
\hline Yellowish-green (2) & $2.5 \mathrm{GY} 5 / 8$ & \\
\hline Yellowish-brown (3) & $2.5 \mathrm{YR} 4 / 6$ & \\
\hline Brown (4) & 2.5 YR $3 / 4$ & \\
\hline Intense brown (5) & 2.5 YR $3 / 6$ & \\
\hline
\end{tabular}


Table 2. Graphical representation of the exocarp color and average of the red, green and blue pigmentation intensities of the exocarp of dovyalis fruits at different stages of maturation, according to the RGB system.

\begin{tabular}{|c|c|c|c|c|}
\hline \multirow{2}{*}{ Fruit maturation stage } & \multirow{2}{*}{ Graphical color representation } & \multicolumn{3}{|c|}{ Exocarp color } \\
\hline & & Red & Green & Blue \\
\hline 1 & & $50.00 \mathrm{a}^{*}$ & $54.80 \mathrm{a}$ & $21.05 \mathrm{a}$ \\
\hline 2 & & $57.65 \mathrm{a}$ & $45.05 \mathrm{a}$ & $21.20 \mathrm{a}$ \\
\hline 3 & & $27.65 \mathrm{~b}$ & $22.15 \mathrm{~b}$ & $15.00 \mathrm{~b}$ \\
\hline 4 & & $21.60 \mathrm{bc}$ & $18.80 \mathrm{~b}$ & $15.30 \mathrm{~b}$ \\
\hline 5 & & $15.30 \mathrm{c}$ & $13.05 \mathrm{~b}$ & $11.55 \mathrm{~b}$ \\
\hline $\mathrm{CV}(\%)$ & & 13.89 & 16.44 & 12.15 \\
\hline
\end{tabular}

* Means followed by the same letter do not differ by the Tukey test at $5 \%$ of probability.

reduction in the fruits happens as maturation advances, due to the seed generally acquiring colors darker than green. This color is closest to black, which, according to the RGB system, represents color absence. The dovyalis fruits in the last stage have the lowest reflectance values, because they are closer to the senescent phase. The same was observed in Aleurites fordii Hemsl. and pigeon fruits (Kaiser et al. 2016, Lima et al. 2016).

The fruit size presented statistical significance throughout the maturation phases (Table 3 ). A greater transversal diameter was verified in the stage 4 , when the fruit was ripe, with a brown exocarp. The transversal diameter was the lowest in fruits at the fifth maturation stage, where the fruit shows an intense brown color, followed by the stages 1 and 2 , which did not differ statistically from the stage 3 or 5 . The longitudinal diameter showed a trend similar to the transversal one, with the highest value in the stage 4. However, fruits with smaller longitudinal diameters were observed in the stage 1 , which did not differ from the stages 2 and 5, but were smaller than in the stage 3.

The growth of dovyalis fruits and their maturation evolution show a conventional pattern of fruit development, with smaller dimensions in the early stages due to incomplete growth, followed by a progressive increase in dimensions in the successive phases, reaching a maximum growth and maturation, and a consequent decrease in size, after the beginning of senescence, as reported by Agustini et al. (2015) for moringa.

This result reflects the changes that occur during the deterioration process, which include the reserve depletion, changes in chemical composition, lipid oxidation, partial protein breakdown, cell membrane alteration, integrity reduction, increased permeability, cell disorganization and other factors that favor fruit physical, physiological and biochemical changes (Villela \& Peres 2004). This behavior can be observed for Spondias purpurea L., which shows a fruit length growing up to the penultimate ripening stage and decreasing in the last stage (Martins et al. 2003), as well as in sesame plants, which, at 75 days after the anthesis, when the fruits reach their maximum transversal diameter, start a reduction of this attribute, as a consequence of their maturation (Lucena et al. 2013).

A significant difference in the fruit biomass was observed among the maturation stages (Table 3).

Table 3. Transversal diameter (TD), longitudinal diameter (LD), fruit dry biomass (FDB), number of seeds (NS) and seed water content (SWC) of dovyalis fruits harvested at different maturation stages.

\begin{tabular}{cccccc}
\hline Maturation stage & TD $(\mathrm{mm})$ & LD $(\mathrm{mm})$ & FDB $(\mathrm{g})$ & NS & SWC $(\%)$ \\
\hline 1 & $15.93 \mathrm{bc} *$ & $14.80 \mathrm{c}$ & $2.21 \mathrm{~d}$ & $2.90 \mathrm{a}$ & $43.10 \mathrm{a}$ \\
2 & $17.17 \mathrm{bc}$ & $16.21 \mathrm{bc}$ & $2.98 \mathrm{bc}$ & $4.10 \mathrm{a}$ & $35.20 \mathrm{~b}$ \\
3 & $17.45 \mathrm{~b}$ & $16.72 \mathrm{~b}$ & $3.29 \mathrm{~b}$ & $4.10 \mathrm{a}$ & $31.90 \mathrm{c}$ \\
4 & $19.00 \mathrm{a}$ & $18.69 \mathrm{a}$ & $4.46 \mathrm{a}$ & $4.75 \mathrm{a}$ & $15.90 \mathrm{~d}$ \\
& $15.73 \mathrm{c}$ & $15.95 \mathrm{bc}$ & $2.61 \mathrm{~cd}$ & $3.75 \mathrm{a}$ & $12.00 \mathrm{e}$ \\
\hline CV $(\%)$ & 4.00 & 3.90 & 8.04 & 24.30 & 3.80 \\
\hline
\end{tabular}

* Means followed by the same letter do not differ statistically from each other by the Tukey test. 
As verified for the fruit growth model, the lowest biomass was verified in the stage 1 green fruits, followed by the stages 2 and 3, where the fruit is still growing, reaching the maximum weight in the fourth stage, when fruit maturation occurs, and finally a biomass regression with fruit degradation beginning in the stage 5 . The collection of seeds must be performed during the fourth stage, because the maximum caliber of the fruits, together with the maximum mass accumulation, indicates that the seeds have reached their maximum point of growth, what may favor their germination and vigor.

Biomass losses due to moisture content reduction occur after the fruits reach their maximum size and complete ripening occurs, and this can be verified in passion fruit, plum and cherry, when the biomass measurements accompany the ripening process (Malgarim et al. 2007, Ávila et al. 2009).

The number of seeds present in the fruits at different stages did not show a variation during fruit maturation. Although this number tended to be lower in the first maturation stage, but not significantly different, what could be a result of small seed sizes before maturation, some seeds were not developed yet and may not have been visible in the initial stages.

The variation in the number of seeds throughout the ripening process is very diverse in different species. For Capsicum chinense Jacq., during maturation, a seed reduction can be observed from 38 to 34 seeds per fruit between the first and last maturation stages, respectively (Gonçalves et al. 2015). Additionally, for two species that belong to the same genus, the number of seeds decreases with the advancement of maturation, changing from an average of 7 to 5 seeds per fruit in Averrhoa bilimbi and from 4 seeds per green fruit of Averrhoa carambola L. to 3.1, on average, seeds per ripe fruit (Oliveira et al. 2011,
Santos et al. 2014). Some species show a larger number of seeds in advanced maturation stages, such as Moringa oleifera Lam., and some species, such as pigeon fruit, do not show variation in the number of seeds between the maturation stages, as verified in this study for dovyalis (Augustini et al. 2015, Lima et al. 2016).

As displayed in Table 3, a decrease in water content was verified in dovyalis seeds with a higher seed moisture in the maturation stage 1 (green). The degree of desiccation gradually increased until reaching its apex in the seeds of the last ripe stage. Carvalho \& Nakagawa (2012) explained that during the ontogeny of the fruit, the seeds show a high water content in the initial phases after the zygote formation, leading to a moisture decrease with variable duration according to the climate, and eventually reaching a fast dehydration phase, demonstrating that the mother plant does not control the seed moisture content.

From the aforementioned information, the decrease in water content can be considered an expected event and a normal behavior for many species, both in plants with dry fruits, such as Mimosa caesalpiniifolia Benth. and Moringa oleifera (Nogueira et al. 2013, Augustini et al. 2015), and plants with fleshy fruits, such as Eugenia involucrata DC. and Allophylus edulis (Oro et al. 2012, Kaiser et al. 2016).

It can be observed that seeds from first stage fruits have a lower germination percentage, being the only treatment different from the others. They took more time to germinate, with the lowest germination speed index, although it was only significantly different from the stage 2 for this variable (Table 4).

The lowest germination percentages and speeds occurred at the maturation stage 1 and were

Table 4. Average germination percentage data (GP), germination speed index (GSI), shoot dry biomass (SHDB), root dry biomass (RDB) and seedling dry biomass (SDB) of dovyalis fruits harvested at different maturation stages.

\begin{tabular}{cccccc}
\hline Maturation stage & GP $(\%)$ & GSI $(\%)$ & SHDB $(\mathrm{mg})$ & RDB $(\mathrm{mg})$ & SDB $(\mathrm{mg})$ \\
\hline 1 & $26 \mathrm{~b} *$ & $0.338 \mathrm{~b}$ & $23.95 \mathrm{~b}$ & $2.85 \mathrm{~b}$ & $26.80 \mathrm{~b}$ \\
2 & $86 \mathrm{a}$ & $0.945 \mathrm{a}$ & $29.38 \mathrm{ab}$ & $12.95 \mathrm{a}$ & $42.33 \mathrm{a}$ \\
3 & $84 \mathrm{a}$ & $0.632 \mathrm{ab}$ & $34.02 \mathrm{a}$ & $8.20 \mathrm{ab}$ & $42.23 \mathrm{a}$ \\
4 & $93 \mathrm{a}$ & $0.732 \mathrm{ab}$ & $34.55 \mathrm{a}$ & $9.43 \mathrm{ab}$ & $43.98 \mathrm{a}$ \\
5 & $71 \mathrm{a}$ & $0.711 \mathrm{ab}$ & $30.38 \mathrm{ab}$ & $11.58 \mathrm{a}$ & $41.95 \mathrm{a}$ \\
\hline CV $(\%)$ & 14.0 & 30.7 & 13.0 & 23.4 & 9.5 \\
\hline * Means followed by the same letter do not differ by the Tukey test at $5 \%$ of probability.
\end{tabular}


due to the seed physiological immaturity in this phase. According to Carvalho \& Nakagawa (2012), for seed maturity physiological determination, physical and physiological characteristics such as water content, seed germination and vigor should be considered. Thus, from the high seed water content in the stage 1, together with the lower germination and germination speed index, it can be concluded that the low vigor at this stage is due to the seeds having not yet reached their physiological maturity.

This information agrees with the statement of Nogueira et al. (2013), which affirm that the exocarp color change of the fruits, together with the reduction of seed water percentage, is effective in helping to determine the seed physiological maturity, what, according to observations from this study, may also be applied for dovyalis fruits. From the second fruit ripening stage, the change in the exocarp color was from green to yellowish-green and did not differ in seed germination percentages and germination speed index until the stage 5, but the seeds continued to lose water during fruit maturation.

In addition to the germination percentage and germination speed index, when the maturation stage interference on physiological seed maturity was studied in order to correlate them with the objective of using the external fruit color as an index to determine the ideal harvest point to obtain seeds with high vigor, another important fact to be verified was the seedling quality generated from germination. When the seeds were not completely mature, they could germinate, but did not result in seedlings as vigorous as those harvested at the appropriate ripening time (Carvalho \& Nakagawa 2012).

This study proves that seeds obtained from fruits harvested during the first maturation stage generate seedlings with the lowest total dry biomass, which differs from the dry biomass of seedlings originating from the four other maturation stages. Similar results can be observed for other species, such as Physalis peruviana and Allophylus edulis (Sbrussi et al. 2014, Kaiser et al. 2016).

This study proves that seeds harvested at the first maturation stage generate seedlings with the lowest shoot, root and total dry biomass. Carvalho \& Nakagawa (2012) affirmed that physiological maturity is reached when the seed shows a greater dry biomass accumulation and a reduction in the water content; changes that are visible in the external appearance of both the fruits and seeds, and that guarantee that fruits harvested with these characteristics present a maximum germinative capacity and seed vigor.

Thus, although the seed dry biomass was not evaluated in this study, considering the water content reduction, the highest germination percentage, germination speed index and exocarp color change, it is possible to affirm that, from the stage 2 of fruit ripening, the dovyalis seeds are in complete physiological maturity, with a high dry biomass content that can be transferred to seedlings during the germination process, and initial development guarantees a greater dry biomass in both the shoot and root, as well as in the whole seedlings.

As in the present study, Mata et al. (2013), evaluating the physiological maturity of Inga striata seeds, also observed that the lowest dry biomass on seedlings shoot and root originated from seeds of fruits harvested on precocious maturation stages. Sbrussi et al. (2014) and Donato et al. (2015) also verified that seedlings extracted from third and fourth maturation stage melons and gooseberries from the second maturation stage showed a greater total dry biomass.

Due to little information in the literature about dovyalis seed quality, future studies should be performed, especially in relation to other germination tests and seedling emergence.

\section{CONCLUSIONS}

1. The dovyalis fruit color during ripening varies from green to intense brown;

2. The fruits reach their largest size and fresh biomass accumulation when the exocarp is brown;

3. Seed removal for propagation purposes should occur when fruits are yellowish-green.

\section{REFERENCES}

AGUSTINI, M. A. B. et al. Physiological maturity of Moringa oleifera (Lam). Revista Inova Ciência \& Tecnologia, v. 8, n. 3, p. 267-278, 2015.

ALMEIDA, E. J. et al. Dovyalis hebecarpa propagation by the use of cuttings. International Journal of Fruit Science, v. 7, n. 1, p. 1-7, 2007.

ALMEIDA, E. J. et al. Propagation of Dovyalis sp. by the process of aerial diving. Revista Brasileira de Fruticultura, v. 26, n. 3, p. 511-514, 2004. 
ÁVILA, A. L. et al. Physiological maturation and seed collection of Eugenia uniflora L. (Pitanga), Santa Maria, RS. Ciência Florestal, v. 19, n. 1, p. 61-68, 2009.

BOCHI, V. C. et al. Polyphenol extraction optimisation from Ceylon gooseberry (Dovyalis hebecarpa) pulp. Food Chemistry, v. 164, n. 1, p. 347-354, 2014.

BRASIL. Ministério da Agricultura, Pecuária e Abastecimento. Regras para análises de sementes. Brasília, DF: MAPA/ACS, 2009.

CARVALHO, N. M.; NAKAGAWA, J. Seeds: science, technology and production. Jaboticabal: Funep, 2012.

CAVALINI, F. C. et al. Harvest point and quality of guavas 'Kumagai' and 'Paluma'. Revista Brasileira de Fruticultura, v. 37, n. 1, p. 64-72, 2015.

DONATO, L. M. S. et al. Physiological quality of melon seeds as a function of fruit maturity stage. Comunicata Scientiae, v. 6, n. 1, p. 49-56, 2015.

FERREIRA, D. F. Sisvar: a computer statistical analysis system. Ciência \& Agrotecnologia, v. 35, n. 6, p. 10391042, 2011.

GONÇALVES, V. D. et al. Physiological maturation of 'red goat' pepper seeds. Revista Caatinga, v. 28, n. 3, p. 137-146, 2015.

JESUS, V. A. M. et al. Rate of seeds and sodium hypochlorite solution on the germination process of papaya seeds. Journal of Seed Science, v. 38, n. 1, p. 57-61, 2016.

KAISER, D. K. et al. Physiological maturity of seeds and colorimetry of fruits of Allophylus edulis [(A. St.-Hil., A. Juss. \& Cambess.) Hieron. ex Niederl.]. Journal of Seed Science, v. 38, n. 2, p. 92-100, 2016.

LESSA, B. F. T. et al. Germination and growth of Enterolobium contortisiliquum (Vell.) Morong seedlings according to the location of the seed in the fruit and temperature regimes. Bioscience Journal, v. 30, n. 5, p. 1474-1483, 2014.

LIMA, P. R. et al. Physiological maturity of tung seeds (Aleurites fordii Hemsl.). Revista de Ciências Agroveterinárias, v. 15, n. 3, p. 208-214, 2016.

LUCENA, A. M. A. et al. Quality of sesame seeds harvested from fruits at different maturation stages. Scientia Plena, v. 9, n. 6, p. 1-7, 2013.

MAGUIRE, J. D. Speed of germination-aid in selection and evaluation for seedling emergence and vigor. Crop Science, v. 2, n. 1, p. 176-177, 1962.

MALGARIM, M. B. et al. Maturity stage and temperature variation in post-harvest quality of plums cv. Reubennel. Revista Brasileira de Agrociência, v. 13, n. 1, p. 61-67, 2007.
MARCOS FILHO, J. Seed physiology of cultivated plants. Londrina: Abrates, 2015.

MARTINS, L. P. et al. Development of fruits of cirigueleira tree (Spondias purpurea L.). Revista Brasileira de Fruticultura, v. 25, n. 1, p. 11-14, 2003.

MATA, M. F. et al. Physiological maturation of inga tree seeds (Inga striata) Benth. Semina: Ciências Agrárias, v. 34, n. 2, p. 549-566, 2013.

MUNSELL, A. H. Munsell book of color. Baltimore: Macbeth Division of Kollmorgen, 1976.

NOGUEIRA, N. W. et al. Physiological maturation and dormancy in sabiá seeds (Mimosa caesalpiniifolia BENTH.). Bioscience Journal, v. 29, n. 4, p. 876-883, 2013.

OLIVEIRA, M. T. R. et al. Biometric and physicochemical characteristics of the fruit, seed and seedling morphology of Averrhoa carambola L. (Oxalidaceae). Revista Brasileira de Sementes, v. 33, n. 2, p. 251-260, 2011.

ORO, P. et al. Physiological maturation of seeds of Eugenia pyriformis Cambess and Eugenia involucrata DC. Biotemas, v. 25, n. 3, p. 11-18, 2012.

RINALDI, A. R. et al. Stem cuttings and substrates in dovyalis asexual propagation. Comunicata Scientiae, v. 8, n. 4, p. 587-595, 2017.

ROTILI, M. C. C. et al. Bioactive compounds, antioxidant and physic-chemical characteristics of the dovyalis fruit. Acta Scientiarum Agronomy, v. 40, e35465, 2018.

RUBIO, F. et al. Stages of fruit maturity on germination performance and oil content of Jatropha curcas Linn. Semina: Ciências Agrárias, v. 34, n. 2, p. 663-668, 2013.

SANTOS, H. H. D. et al. Morphology of fruits, seeds and seedlings of Averrhoa bilimbi L. originating from two stages of ripening. Ciência Rural, v. 44, n. 11, p. 19952002, 2014.

SBRUSSI, C. A. G. et al. Maturation stages of fruit development and physiological seed quality in Physalis peruviana. Revista Ciência Agronômica, v. 45, n. 3, p. 543-549, 2014.

VILLELA, F. A.; PERES, W. B. Coleta, secagem e beneficiamento de sementes. In: FERREIRA, A. G.; BORGUETTI, R. Germinação: do básico ao aplicado. Porto Alegre: Artmed, 2004. p. 265-281.

ZUCARELI, V. et al. Influence of light and temperature on the germination of Passiflora incarnata L. seeds. Journal of Seed Science, v. 37, n. 2, p. 162-167, 2015. 